\title{
Geochemical Compositions of Marine Fossils as Proxies for Reconstructing Ancient Environmental Conditions
}

\author{
László Kocsis*
}

\begin{abstract}
A brief summary is given here about some of the geochemical methodologies that are often used to obtain information from fossils and sediments about the past environment. Such methods are frequently applied in our project in which the formation of Paleogene phosphate sequences in North Africa is investigated. These layers were deposited in shallow marine seas during a period of extreme warm climate with a high $\mathrm{CO}_{2} \mathrm{Con}_{-}$ centration in the atmosphere. Some of the characteristics of this greenhouse interval are similar to the modern anthropogenic situation hence it is intensively investigated from several aspects by many scientists. Here the geochemical compositions of fossils deposited during this time are discussed, focusing on how the data are obtained and how they could be evaluated in terms of palaeo-environmental conditions.
\end{abstract}

Keywords: Fossils · Palaeo-environment $\cdot$ Phosphate $\cdot$ Rare earth elements $\cdot$ Stable isotopes

\section{Introduction}

Geochemistry is a multidisciplinary field of earth-sciences and it deals with the relative abundance, distribution and cycling of the Earth's chemical elements and isotopes in time and space. It studies not only the solid earth (e.g. rocks, soils, minerals) but also the atmosphere, hydrosphere, biosphere and the chemical composition of other planets. It describes the geological and chemical processes that govern the interactions between or within these domains. Hence geochemical methods are widely applied in several geology-related themes such as petrology, mineralogy, paleontology, sedimentology, hydrology where the chemical and/or isotopic compositions of specified samples can be interpreted in a geological context.

\footnotetext{
${ }^{*}$ Correspondence: Dr. L. Kocsis

Research Fellow, Ambizione SNF Université de Lausanne

Faculté des géosciences et de l'environnement Institut de Minéralogie et Géochimie

UNIL - Dorigny - Anthropole

$\mathrm{CH}-1015$ Lausanne

Tel.: +41216924349

E-mail: laszlo.kocsis@unil.ch
}

Geochemistry is often applied to fossils and sediments in order to describe the past environment. Fossils are remnants of ancient life forms that were buried and partially preserved in the sedimentary record. In order to obtain reliable geochemical data about past living conditions, the fossils should retain some of the original physical and chemical character of their tissues, e.g. the original mineralogy of their hard tissues. These biominerals are formed during life by metabolism and exchange of elements between the organisms and their environment. Hence their chemical compositions reflect the environment in which they live (Fig. 1).[1-4] The most common biominerals are the two calcium carbonate $\left(\mathrm{CaCO}_{3}\right)$ polymorphs, calcite and aragonite, apatite $\left(\mathrm{Ca}_{5}\left(\mathrm{PO}_{4}\right)_{3}(\mathrm{OH}, \mathrm{F})\right)$ and opal $\left(\mathrm{SiO}_{2} \times \mathrm{nH}_{2} \mathrm{O}\right)$, which appear as hard parts forming shells, valves, tests, endo- or exoskeletons. All of these have the potential to preserve valuable information from past ecological conditions. However, it is critical to any palaeo-environmental study to demonstrate the good chemical preservation of the fossils. The process of diagenesis (fossilization) can influence and change the biominerals and their chemical and isotopic compositions after deposition. Hence the collected fossils must be tested for preservation state with geochemical methods, see e.g. refs $[5,6]$.

Depending on the methods used, geochemical composition of fossils can be linked to past climatic and oceanic conditions, see e.g. refs [1,7-9], it can be relevant to stratigraphy for correlating sediment series, see e.g. refs $[10,11]$, or the habitat of modern and ancient organisms

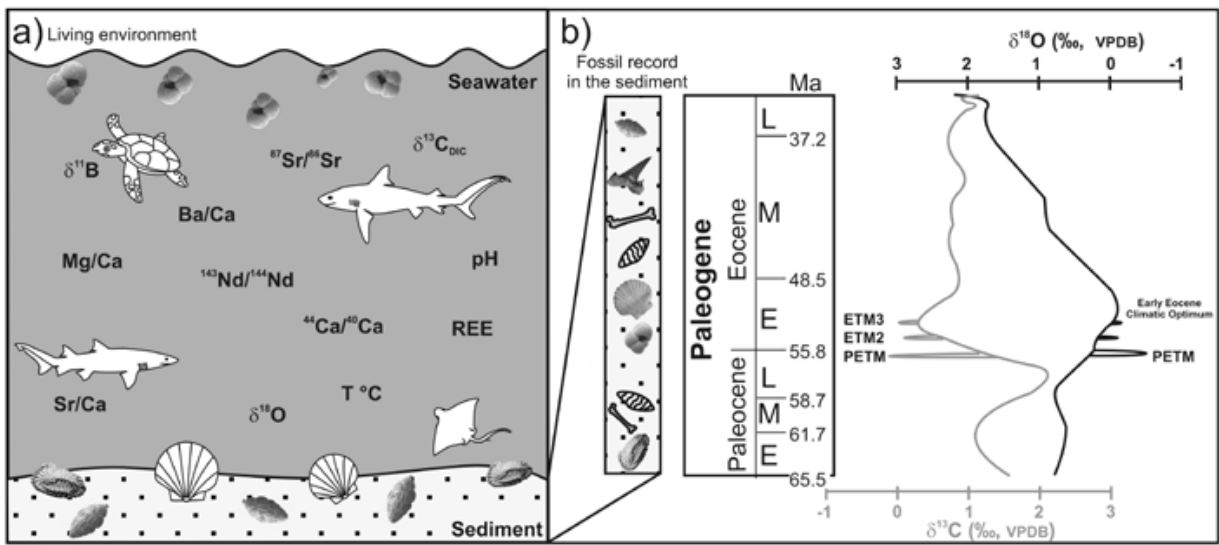

Fig. 1. a) Simplified illustration of how living organisms interact with their environment and some geochemical proxies that might be recorded in their biominerals. b) Sediment with different type of fossils (not to scale) that can be used for different geochemical analyses. Next to it is the time scale and age of the sediments and fossils that investigated by our project and the global marine oxygen and carbon isotopic record showing the major thermal and negative CIE (carbon isotope excursion) events. ${ }^{[1-3]}$ 
can be constrained. ${ }^{[12-15]}$ In our previous research radiogenic and stable isotope ratios together with trace element compositions of fossils were successfully applied to tracing palaeo-climatic and palaeo-oceanic conditions, ${ }^{[16-18]}$ palaeo-habitat ${ }^{[19,20]}$ and describing fossilization processes. ${ }^{[21,22]}$

\section{Research Background}

Our most recent research focuses on phosphorite series in North Africa which were deposited during the Early Paleogene ( 60-40 million years ago (Ma), Fig. 1b). This period was very warm and it contains the most recent greenhouse interval with high $\mathrm{CO}_{2}$ concentration in the atmosphere $\left(\sim 2000 \mathrm{ppm}^{[23]}\right)$ and no permanent ice in the polar regions. However, an even warmer extreme climatic event occurred about 55.8 $\mathrm{Ma}$ at the Paleocene-Eocene boundary, the so-called Paleocene-Eocene Thermal Maximum (PETM). Evidence for this global hyperthermal event is provided for example by oxygen isotope $\left(\delta^{18} \mathrm{O}\right)$ excursion in marine biogenic calcite (Fig. 1b), ${ }^{11,24,25]}$ increased $\mathrm{Mg} / \mathrm{Ca}$ values in plankton and benthic organisms, ${ }^{[26,27]}$ or by the biomarker temperature proxy of $\operatorname{TEX}_{86}{ }^{[28,29]}$ The extreme temperature has been recorded from the tropical sea surface to deep arctic water and also in terrestrial environments, and the magnitude of the observed changes is larger towards higher latitudes. ${ }^{[26,28]}$ The PETM is also associated with a negative $2.5-6 \%$ carbon isotope $\left(\delta^{13} \mathrm{C}\right)$ excursion (CIE) (Fig. 1b), ${ }^{[10,24,25,30]}$ which reflects a geologically rapid injection of a large mass of ${ }^{12} \mathrm{C}$-enriched carbon into the ocean/atmosphere system. Several primary sources of this isotopically light carbon have been proposed, for instance dissociation of methane hydrate released from seafloor sediment, ${ }^{[31]}$ however, no single satisfactory explanation exists as yet, e.g. ref. [32]. Other short term hyperthermals coupled with negative CIE have been reported from Early Eocene marine sediments (Fig. 1b, Eocene Thermal Maximum (ETM) $2 \& 3^{[2,3]}$, however they show less pronounced isotope excursions. In many ways these events, especially the PETM, represent natural experiments analogous to the modern anthropogenic situation of global warming. Therefore the PETM has become an important geological case study in global changes, and many of the event's characteristics and mechanisms have been under intensive study.

We are studying Paleogene shallow marine phosphorite series in North Africa. These beds are very rich in vertebrate fossils such as shark teeth, crocodile and turtle remains. Carbonate fossils are almost absent or reduced to intercalated layers like marl and clay. Our first result from Tunisia yielded very low $\delta^{13} \mathrm{C}$ values from shark teeth and coprolites (fossilized faecal pellets of fish, for example) with a large negative shift (3-4\%o) in the upper part of the studied sediment sections ${ }^{[18]}$ but without any remarkable change in $\delta^{18} \mathrm{O}$ values. The observed CIE was proposed to mark the Paleocene-Eocene boundary, ${ }^{[18]}$ however, the $\delta^{13} \mathrm{C}$ values are extremely low and they might relate to local processes such as phosphatization. This calls for further research to investigate whether the observed CIE is due to local diagenetic processes or indeed it links to the global perturbation in the carbon cycle at the Paleocene-Eocene boundary. The project further deals with questions such as, whether it is possible to trace the observed amplitude of the CIE in other low latitude shallow basins, whether the younger CIE events can be seen in these deposits, how these regions responded to the sudden increases, pulses of $\mathrm{CO}_{2}$ in the atmosphere during the Early Paleogene and why no thermal response in $\delta^{18} \mathrm{O}$ values were observed in some sections. To answer these questions detailed fieldwork in Tunisia and Morocco has been organized and sediments and well-preserved fossils have been collected in order to constrain further the palaeo-environmental conditions.

\subsection{Biogenic Apatite Fossils}

Because calcareous fossils are scarce and biogenic apatite are so abundant in these sediments, the characteristic fossilization features of phosphate remains and their preparation for stable isotope measurements are discussed in more detail. A general apatite chemical formula can be given as $\mathrm{Ca}_{5}\left(\mathrm{PO}_{4}, \mathrm{CO}_{3}\right)_{3}\left(\mathrm{CO}_{3}, \mathrm{~F}, \mathrm{OH}\right)$ highlighting the most common anion substitutions, while $\mathrm{Ca}$ can be replaced by many cations such as $\mathrm{Na}, \mathrm{Sr}, \mathrm{Ba}, \mathrm{Mn}$, rare earth elements (REE) or U, see e.g. ref. [4]. The most widespread apatite fossils are shark teeth. The external part of their cusp is covered by enameloid composed of large wellcrystallized fluor-apatite ( 3-4wt\% of F) with very low organic and carbonate contents. Their root and internal parts are built up of dentine (similar structure to bone) that consists of smaller crystallites and contains larger amount of organics $(\sim 10$ $\mathrm{wt} \%$ ) and carbonates ( up to $6-8 \mathrm{wt} \%){ }^{[4]}$

During early fossilization generally the organic contents, mostly collagens, decompose first and open up pore spaces. These are sometimes filled up by early secondary apatite or later by other secondary minerals, depending on the local burial conditions (redox, $\mathrm{pH}$, available elements, etc.). During these early processes certain trace element can be enriched in the fossils due to interaction with the pore fluid. The most remarkable changes are the increased REE and U concentrations, see e.g. refs [5,33,34]. Clearly, this trace element uptake could modify and often overprints the biological trace element signal, but the incorporated elements provide an excellent tool to constrain burial conditions, taphonomy and to distinguish possible reworked specimens. ${ }^{[35,36]}$ Many studies showed that even if such trace element exchange is a characteristic feature of phosphatic fossils, stable oxygen and carbon isotope compositions of tooth enamel can still reveal reliable ecological information, see e.g. refs [12,13,19,20,37-39].

The $\mathrm{PO}_{4}{ }^{3-}$ and $\mathrm{CO}_{3}{ }^{2-}$ groups in the apatite structure can be measured separately for their oxygen isotope compositions $\left(\delta^{18} \mathrm{O}_{\mathrm{PO} 4}\right.$ and $\left.\delta^{18} \mathrm{O}_{\mathrm{CO} 3}\right)$. The strong $\mathrm{P}-\mathrm{O}$ bond in the phosphate makes it more resistant to diagenetic alteration compare to carbonate, see e.g. ref. [13] especially under inorganic conditions. In contrast, under strong microbiologically mediated conditions phosphate oxygen might be affected as well, see $e . g$. refs $[40,41]$. Experiments however showed that when originally wellcrystallized enamel was tested it retained its phosphate oxygen isotope composition under both conditions. ${ }^{[41]}$

In the following, our sampling strategy and the main preparation techniques focusing on the chemistry prior to stable isotope analyses are described and in the end a few implications of the data are given.

\section{Methodology}

The elemental or isotopic composition of such old fossils could have changed or altered during diagenesis. This can include re-crystallization, secondary mineral precipitation, dissolution, trace element exchange with the burial fluid, etc., which all cause difficulties in the interpretation of the obtained geochemical data. Therefore, the samples must be scrutinized and carefully characterized before geochemical analyses. This involves macro- and microscopic observations (e.g. optical microscope, secondary electron microscope (SEM) images) and mineralogical characterization (X-ray diffraction (XRD)). This can be followed by checking the fossils for major and trace element distributions (e.g. electron microprobe analyses (EPMA), cathode luminescence (CL), laser ablationinductively coupled plasma-mass spectrometry (LA-ICP-MS)) and finally the well-preserved samples can be prepared for different isotope analyses.

\subsection{Testing for Preservation State}

Sediments and macro-fossils (shark teeth, coprolites, bone remains) are directly collected during fieldwork in North Africa. In the laboratory these fossils are cleaned in distilled water and some are 
tested for mineralogical composition by XRD (Fig. 2). Others are cut and embedded in resin and polished to provide a flat surface and then are analyzed for major and trace element compositions by EPMA and LA-ICP-MS (Fig. 3).

The clay-rich sediments are disaggregated with $10 \% \mathrm{H}_{2} \mathrm{O}_{2}$ in an ultrasonic bath;

\subsubsection{Phosphatic Fossils} $\left[\mathrm{Ca}_{5}\left(\mathrm{PO}_{4}, \mathrm{CO}_{3}\right)_{3}\left(\mathrm{CO}_{3}, \mathrm{~F}, \mathrm{OH}\right)\right]$

Biogenic apatite samples are either crushed up in agate mortar or the enameloid is shaven off the teeth by a micro-drill. Samples destined for isotopic study are generally pre-treated in two steps following the methods of Koch et al. ${ }^{[43]}$ About used adapted after O'Neil et al. ${ }^{[44]}$ and Dettman et al. ${ }^{[45]}$ One to five $\mathrm{mg}$ of precleaned powder is weighed into a $2 \mathrm{ml}$ safe lock vessel and dissolved in $800 \mu 12 \mathrm{M} \mathrm{HF}$ overnight, then centrifuged and the HFsolution extracted into a new vessel while the $\mathrm{CaF}_{2}$ residue is left behind. The aliquot is neutralized by $143 \mu \mathrm{l} 25 \% \mathrm{NH}_{4} \mathrm{OH}$ so-

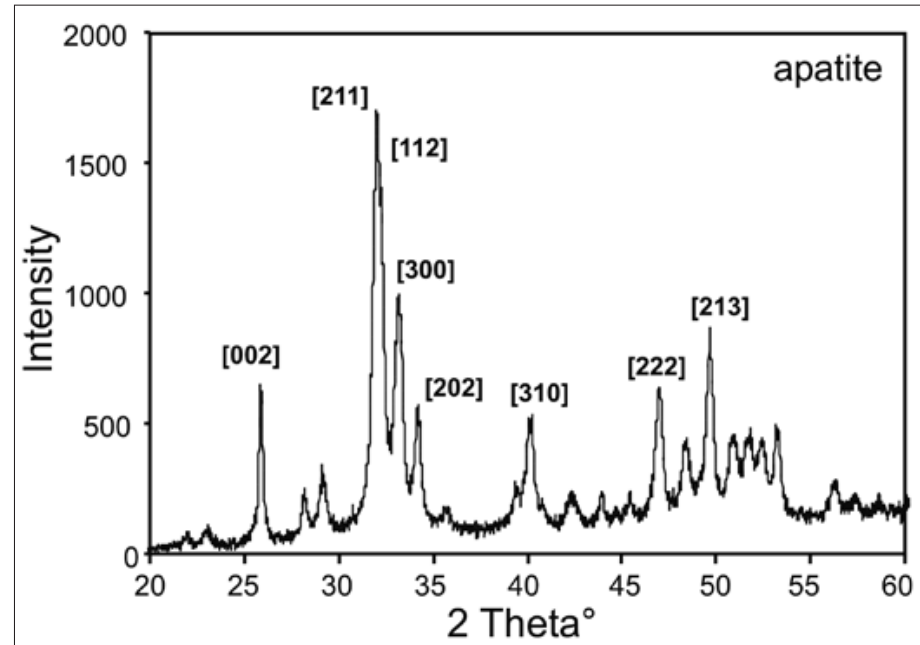

Fig. 2. Macro-fossils are often checked for their mineralogical composition, e.g. typical X-ray diffractogram of biogenic apatite. Above the corresponding Miller indices are shown for the highest intensities.

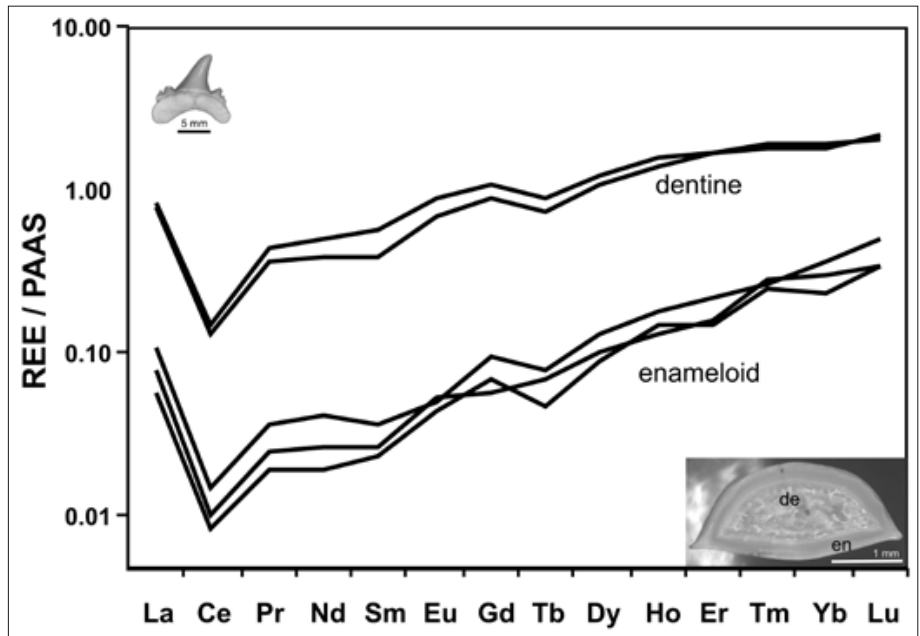

Fig. 3. Shark teeth are cut, embedded in resin, polished and then analysed by LA-ICP-MS. The obtained rare earth element concentration data of enameloid and dentine are shown as PAAS shale normalized REE patterns. These REE distributions are very similar to the seawater REE pattern. washed with distilled water and sieved (mesh size 125 and $250 \mu \mathrm{m}$ ), then calcareous micro-fossils are picked under a binocular microscope. The state of preservation is examined using scanning electron microscope (Fig. 4).

\subsection{Preparation for Stable Isotope Analyses}

\subsubsection{Calcareous Micro-fossils} $[\mathrm{CaCO}]$

The fossils are directly analyzed for stable carbon and oxygen isotopes using a Gasbench II coupled to a Finnigan MAT Delta Plus XL mass spectrometer at the University of Lausanne. In this method about 50-200 $\mu \mathrm{g}$ samples are weighed in vessels where they are reacted with $99 \%$ phosphoric acid and after a reaction time of $1 \mathrm{~h}$ the produced $\mathrm{CO}_{2}$ is introduced to the mass spectrometer. The measured isotopic ratios are normalized to an in-house Carrara marble calcite standard that has been calibrated against the international calcite standard of NBS-19. The analytical precision for this method is better than $\pm 0.1 \%$ o for $\mathrm{O}$ and $\mathrm{C}$ isotopes, see $e . g$. ref. [42]. Oxygen and carbon isotope compositions are expressed in the $\delta$-notation relative to VPDB (Vienna Pee Dee Belemnite):

$$
\begin{gathered}
\delta^{18} \mathrm{O} \text { or } \delta^{13} \mathrm{C} \text { in } \% \circ=\left(\frac{R_{\text {Sample }}}{R_{\text {VPDB }}}-1\right) \times 1000 \\
R={ }^{18} \mathrm{O} /{ }^{16} \mathrm{O} \text { or }{ }^{13} \mathrm{C} /{ }^{12} \mathrm{C}
\end{gathered}
$$

5-10 $\mathrm{mg}$ of pulverized sample is weighed into a $2 \mathrm{ml}$ safe lock vessel, soaked for 24 h in $2-2.5 \% \mathrm{NaOCl}$ (or $10 \% \mathrm{H}_{2} \mathrm{O}_{2}$ ) to remove any residual soluble organic matter, washed several times in distilled water and then soaked for another 6-12 $\mathrm{h}$ in $1 \mathrm{M}$ acetic acid-Ca-acetate buffer ( $\mathrm{pH} 4.5$ ), to remove exogenous carbonates. International NBS-120c phosphorite rock standards are run together with each preparation. At this stage 1.5-3 mg sub-samples are weighed for $\delta^{13} \mathrm{C}$ and $\delta^{18} \mathrm{O}$ analyses in the $\mathrm{CO}_{3}{ }^{2-}$ component and measured in the same way as described above for the calcareous micro-fossils.

The chemical separation of the $\mathrm{PO}_{4}^{3-}$ group needs further steps where a rapid silver phosphate precipitation method is lution; mixed well with a mini-shaker for 1 min, which gives a solution $\mathrm{pH}$ of $\sim 7$. Solutions with variable $\mathrm{pH}$ were tested and $\pm 1 \mathrm{pH}$ unit did not have any effect on the oxygen isotopic composition. Then with the addition of $800 \mu \mathrm{l}$ of $2 \mathrm{M} \mathrm{AgNO}_{3}$ solution an immediate precipitation of tiny yellow $\mathrm{Ag}_{3} \mathrm{PO}_{4}$ crystals is visible. After $\sim 30$ mins when the crystals have settled down, the sample is centrifuged then washed at least twice with distilled $\mathrm{H}_{2} \mathrm{O}$ and again centrifuged in-between. The washed silver phosphate powder is dried at $50-70{ }^{\circ} \mathrm{C}$ overnight. NBS-120c standard is prepared parallel with each separation for quality control. Finally, triplicate measurements of about 500-700 $\mu \mathrm{g}$ of $\mathrm{Ag}_{3} \mathrm{PO}_{4}$ weighed in silver capsules are made.
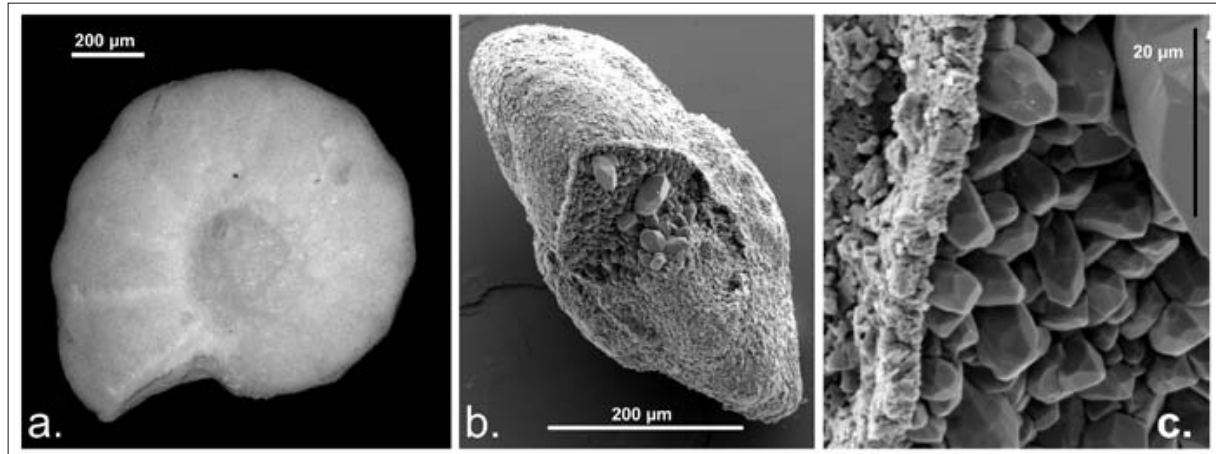

Fig. 4. Micro-fossils are tested for preservation with optical microscope and secondary electron microscope (SEM). Example of benthic foraminifera: a) LEXT laser-microscope image; b,c) SEM images showing the secondary mineral infills in the fossils. 
The silver phosphate is converted to $\mathrm{CO}$ at $1450{ }^{\circ} \mathrm{C}$ via reduction with graphite for oxygen isotope measurements using a high-temperature conversion elemental analyzer (TC/EA) ${ }^{[46]}$ coupled to a Finnigan MAT Delta Plus XL mass spectrometer. The results are corrected to $\mathrm{Ag}_{3} \mathrm{PO}$ phosphate standards (e.g. TU-1, TU-2), ${ }^{4}{ }^{46]}$ that normally have $\pm 0.3 \%$ standard deviations during measurements. Oxygen isotope compositions are expressed in the $\delta$-notation relative to Vienna Standard Mean Ocean Water (VSMOW).

\section{Preliminary Results}

The data provided by the discussed analyses can already give some clues about the ancient environmental conditions. Two palaeo-environmental signals should be distinguished: the one that links to ancient living condition (e.g. palaeo-temperature, palaeo-climate) and the other that relates to early diagenetic environment (e.g. ancient pore-water chemistry). Hence in the following, the analyses are briefly discussed in the view of the Paleogene warm climate and in terms of ancient burial conditions with some examples from previous results and some new data.

\subsection{Palaeo-temperature}

Oxygen isotopic compositions of marine carbonates and phosphates are the function of temperature and seawater isotopic composition $\left(\delta^{18} \mathrm{O}_{\mathrm{H} 2 \mathrm{O}}\right) \cdot[36,47,48]$ Therefore if the seawater isotopic composition is known then direct temperature data can be calculated from the isotopic compositions of the fossils. Seawater oxygen isotopic composition generally fluctuates, in relation to the amount of permanent ice in the polar regions, between about -1 and $0.5 \%$, respectively in greenhouse and icehouse periods. In the warm world of the Paleocene-Eocene a $-1 \%$ ovalue would be applicable, however, in small basins evaporation would increase or freshwater input would decrease the local seawater isotopic composition

Due to the diagenetic alteration of the calcareous micro-fossils (Fig. 4), the ambient seawater temperature is calculated from $\delta^{18} \mathrm{O}_{\mathrm{PO} 4}$ values of shark teeth enameloid instead $\left(\right.$ e.g. $\mathrm{T}\left({ }^{\circ} \mathrm{C}\right)=113.3-4.38 *\left(\delta^{18} \mathrm{O}_{\mathrm{PO} 4}\right.$ $\left.\left.-\delta^{18} \mathrm{O}_{\mathrm{H} 2 \mathrm{O}}\right)^{[37]}\right)$. The first $\delta^{18} \mathrm{O}_{\mathrm{PO} 4}$ data reported from Paleocene-Eocene Tunisian shark teeth are between 19.8-21.1\%o, , ${ }^{[18]}$ while new data from younger Early Eocene beds show a lower range of 18.7-20.5\%o. ${ }^{[49]}$ This general decrease in the $\delta^{18} \mathrm{O}_{\mathrm{PO} 4}$ values in time clearly reflects changes in past conditions. It most possibly links to the general warming trend that appeared during the early Eocene, termed as Early Eocene Climatic Optimum (Fig. 1b). But future analyses of $\delta^{13} \mathrm{C}$ composition of the samples and better biostratigraphy are necessary to see whether this warming can be further associated to one of the Eocene Thermal Maximum events.

However, the lower $\delta^{18} \mathrm{O}_{\mathrm{PO} 4}$ values could equally be explained by strong freshwater input in the local marine basin which could have lowered the isotopic composition of the fossils. But since no sedimentological or paleontological indications are known for this influence, this alternative is rejected. On the other hand, the relatively high $\delta^{18} \mathrm{O}_{\mathrm{PO} 4}$ values in the shark teeth from the older beds could relate to enhanced evaporation under a semi-closed condition which occasionally existed in the Tunisian phosphate basin.

If all local factors such as evaporation and palaeo-geographic situation are considered then a seawater $\delta^{18} \mathrm{O}_{\text {H2O }}$ value of $-0.5 \%$ o can be used from which a habitat temperature range of $19-29{ }^{\circ} \mathrm{C}$ can be calculated for these Paleocene-Eocene sharks.

\subsection{Pore-fluid Chemistry}

Rare earth elements (REE) have very low concentrations in modern biominerals $(<1 \mathrm{ppm})$. The phosphatic fossils from North African phosphate beds however yielded total REE concentration in the range of 10-400 ppm with lower concentrations in enameloid and higher in dentine, bones and coprolites. This indicates interaction with pore fluid during early diagenesis and it also reflects the different susceptibility for trace element exchange by the different archives (Fig. 3). Extensive late diagenetic re-crystallization controlled by bulk crystal-chemical properties would predict middle-REE enrichment. [50] However, during early diagenesis quantitative REE uptake plays a more important role, hence the relative distributions of the
REE are still likely to reflect those of the contemporary pore fluid. ${ }^{[50-52]}$ The PAAS (post-Archean Australian Shale) normalized REE patterns of the fossils display negative Ce-anomaly and small heavyREE enrichments for most of the analyzed teeth (Fig. 3), hence it can be concluded that no late diagenetic re-crystallization and late REE uptake affected the fossils. Moreover, the observed REE patterns are similar to that of modern oxic-suboxic seawater ${ }^{[33]}$ indicating that the early diagenetic fluid was dominated by seawater.

\subsection{Local Process vs. Global $\delta^{13} \mathrm{C}$ Signal?}

So far the extracted micro-fossils have been mostly foraminifera (Fig. 4), a large group of Protozoa, and ostracoda, small crustaceans protected by calcareous shells. Both groups generally grow calcite biomineral. Many shells show different diagenetic features, for example secondary calcite infills (Fig. 4) or early diagenetic dolomite overgrowth. Hence the isotopic compositions of these fossils often deviate from expected normal marine values (Fig. 5). This indicates the effect of early diagenetic fluids. The very low $\delta^{13} \mathrm{C}$ values could reflect the enhanced re-cycling of organic matter in these sediments that lowered the isotopic compositions of dissolved inorganic carbon (DIC) in the pore fluid, from which the secondary minerals precipitated inside the shells (Fig. 4c). This reveals that a complex diagenetic environment existed during phosphorite formation. Whether the few even lower $\delta^{13} \mathrm{C}$ values $(<-10 \%$ o can be linked to some of the globally observed negative CIE anomalies during the Paleogene (Fig. 1b) remains to be investigated.

Received: June 28, 2011

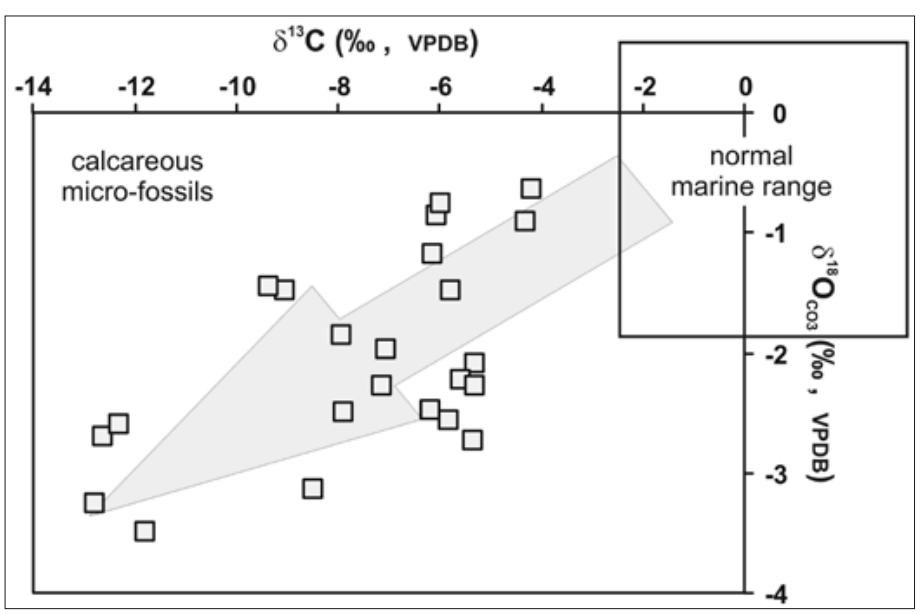

Fig. 5. $\delta^{13} \mathrm{C}$ versus $\delta^{18} \mathrm{O}$ stable isotope plot. Note that the calcareous micro-fossils differ from expected normal marine carbonate isotopic compositions, which can be linked to the secondary mineral phases precipitated in the shells (cf. Fig. $4 b, c)$. The grey arrow shows the direction of diagenesis. 
[1] J. Zachos, M. Pagani, L. Sloan, E. Thomas, K. Billups, Science 2001, 292, 686.

[2] L. J. Lourens, A. Sluijs, D. Kroon, J. C. Zachos, E. Thomas, U. Röhl, J. Bowles, I. Raffi, Nature 2005, 435, 1083.

[3] C. Agnini, P. Macrì, J. Backman, H. Brinkhuis, E. Fornaciari, L. Giusberti, V. Luciani, D. Rio, A. Sluijs, F. Speranza, Paleoceanography $\mathbf{2 0 0 9 ,}$ 24, doi: 10.1029/2008PA001649.

[4] H. C. W. Skinner, A. H. Jahren, in 'Treaties on Geochemistry - 8. Biogeochemistry', Ed. H. D. Holland, K. K. Turekian, Elsevier, 2003, p. 116

[5] P. A. Allison, K. Pye, Palaios 1994, 9, 561.

[6] C. N. Trueman, N. Tuross, in 'Review in Mineralogy and Geochemistry - 48. Phosphate', Ed. J. M. Kohn, J. Rakovan, J. M. Hughes, Mineralogical Society of America, Washington, 2002 , p. 489.

[7] H. Staudigel, P. Doyle, A. Zindler, Earth Planet. Sci. Lett. 1985, 76, 45.

[8] K. G. Miller, R. G. Fairbanks, G. S. Mountain, Paleoceanography 1987, 2, 1, doi:10.1029/ PA002i001p00001.

[9] M. Frank, Rev. Geophys. 2002, 40, 1 .

[10] P. L. Koch, J. C. Zachos, P. D. Gingerich, Nature, 1992, 358, 319.

[11] J. M. McArthur, R. J. Howarth, T. R. Bailey, J. Geol. 2001, 109, 155.

[12] T. W. Vennemann, E. Hegner, G. Cliff, W. G. Benz, Geochim. Cosmochim. Acta 2001, 65, 1583.

[13] J. M. Kohn, E. T. Cerling, in 'Review in Mineralogy and Geochemistry - 48. Phosphate', Ed. J. M. Kohn, J. Rakovan, J. M. Hughes, Mineralogical Society of America, Washington, 2002, p. 455.

[14] T. Tütken, Ph. D. Thesis, Eberhard-KarlsUniversität Tübingen, Germany, 2003.

[15] A. Bernard, C. Lécuyer, P. Vincent, R. Amiot, N. Bardet, E. Buffetaut, G. Cuny, F. Fourel, F. Martineau, J.-M. Mazin, A. Prieur, Science 2010, 328, 1379 .

[16] L. Kocsis, T. W. Vennemann, D. Fontignie, C. Baumgartner, A. Montanari, B. Jelen, Paleoceanography 2008, 23, doi:10.1029/ 2007PA001540.

[17] L. Kocsis, T. W. Vennemann, E. Hegner, D. Fontignie, T. Tütken, Palaeogeogr. Palaeoclimat. Palaeoecol. 2009, 271, 117.

[18] A. Ounis, L. Kocsis, F. Chaabani, H.-R. Pfeifer, Palaeogeogr. Palaeoclimat. Palaeoecol. 2008, 268, 1.

[19] L. Kocsis, T. W. Vennemann, D. Fontignie, Geology 2007, 35, 451.

[20] L. Kocsis, A. Ösi, T. W. Vennemann, C. N. Trueman, M. R. Palmer, Palaeogeogr. Palaeoclimat. Palaeoecol. 2009, 280, 532.

[21] L. Kocsis, C. N. Trueman, M. R. Palmer, Geochim. Cosmochim. Acta 2010, 74, 6077.

[22] C. N. Trueman, L. Kocsis, M. R. Palmer, C. Dewdney, Palaeogeogr. Palaeoclimat. Palaeoecol. 2011, 310, 124.

[23] P. N. Pearson, M. R. Palmer, Nature 2000, 406 695.

[24] J. P. Kennett, L. D. Stott, Nature 1991, 353, 225.

[25] D. Thomas, J. Zachos, T. Bralower, E. Thomas, S. Bohaty, Geology 2002, 30, 1067.

[26] J. C. Zachos, M. W. Wara, S. Bohaty, M. L. Delaney, M. R. Petrizzo, A. Brill, T. J. Bralower, I. Premoli-Silva, Science 2003, 302, 1151.

[27] A. Tripati, H. Elderfield, Science 2005, 308, 1894

[28] A. Sluijs, S. Schouten, M. Pagani, M. Woltering, H. Brinkhuis, J. S. Sinninghe Damsté, G. R Dickens, M. Huber, G.-J. Reichart, R. Stein, J Matthiessen, L. J. Lourens, N. Pedentchouk, J. Backman, K. Moran, Expedition 302 Scientists, Nature 2006, 441, 610

[29] J. C. Zachos, S. Schouten, S. Bohaty, T. Quattlebaum, A. Sluijs, H. Brinkhuis, S. Gibbs, T. J. Bralower, Geology 2006, 34, 737.
[30] M. Pagani, N. Pedentchouk, M. Huber, A. Sluijs, S. Schouten, H. Brinkhuis, J. S. Sinninghe Damste, G. R. Dickens, the Expedition 302 Scientists, Nature, 2006, 442, 671 .

[31] G. R. Dickens, J. R. O'Neil, D. K. Rea, R. M. Owen, Paleoceanography 1995, 10, 965.

[32] J. A. Higgins, D. P. Schrag, Earth Planet. Sci. Lett. 2006, 245, 523.

[33] H. Elderfield, R. Pagett, Sci. Total Environ. 1986, 49, 175.

[34] Y. Kolodny, B. Luz, M. Sander, A.W. Clemens, Palaeogeogr. Palaeoclimat. Palaeoecol. 1996, 126, 161.

[35] C. N. Trueman, M. J. Benton, Geology 1997, 25, 263.

[36] B. J. MacFadden, J. Labs-Hochstein, R. C. Hulbert, J. A. Baskin, Jr., Geology 2007, 35, 123.

[37] Y. Kolodny, B. Luz, O. Navon, Earth Planet. Sci. Lett. 1983, 64, 398.

[38] Y. Kolodny, B. Luz, in 'Stable Isotope Geochemistry: A Tribute to Samual Epstein', Ed. H. P. Taylor, J. R. O'Neil, I. R. Kaplan, Geochem. Soc. Spec. Publ. 3, 1991, p. 105.

[39] T. W. Vennemann, E. Hegner, Palaeogeogr. Palaeoclimatol. Palaeoecol. 1998, 142, 107.

[40] R. E. Blake, J. R. O'Neil, G. A. Garcia, Geochim. Cosmochim. Acta 1997, 61, 4411.

[41] A. Zazzo, C. Lécuyer, A. Mariotti, Geochim. Cosmochim. Acta 2004, 68, 1.

[42] C. Spoetl, T. W. Vennemann, Rapid Commun. Mass Spectrom. 2003, 17, 1004.

[43] P. L. Koch, N.Tuross, M. L. Fogel, J. Archaeol. Sci. 1997, 24, 417.

[44] J. R. O'Neil, L. J. Roe, E. Reinhard, R. E. Blake, Isr. J. Earth-Sci. 1994, 43, 203.

[45] D. L. Dettman, M. J. Kohn, J. Quade, F. J Ryerson, T. P. Ojha, S. Hamidullah, Geology 2001, 29, 31.

[46] T. W. Vennemann, H. C. Fricke, R. E. Blake, J. R. O'Neil, A. Colman, Chem. Geol. 2002, 185, 321.

[47] J. R. O’Neil, R. N. Clayton, T. K. Mayeda, J. Chem. Phys. 1969, 51, 5547.

[48] J. Erez, B. Luz, Geochim. Cosmochim. Acta 1983, 47, 1025

[49] L. Kocsis, A. Ounis, F. Chaabani, N.M. Salah, Int. J. Earth. Sci. 2011, submitted.

[50] B. Reynard, C. Lécuyer, P. Grandjean, Chem. Geol. 1999, 155, 233.

[51] P. Picard, C. Lécuyer, J.-A. Barrat, J.-P. Garcia, G. Dromart, S. M. F. Sheppard, Chem. Geol. 2002, 186, 1.

[52] C. Lécuyer, B. Reynard, P. Grandjean, Chem. Geol. 2004, 204, 63. 